\title{
Parotid Gland Hemangioma
}

National Cancer Institute

\section{Source}

National Cancer Institute. Parotid Gland Hemangioma. NCI Thesaurus. Code C5397.

A hemangioma arising from the parotid gland. 